\title{
Labour Standards Regulation in a Globalised Economy: A Review of Existing Paradigms
}

\author{
Angela Dziedzom Akorsu \\ Department of Labour and Human Resource Studies \\ School for Development Studies \\ University of Cape Coast \\ E-mail:aakorsu@ucc.edu.gh \\ DOI//http://dx.doi.org/10.4314/gjds.v15i2.4
}

\begin{abstract}
Recent global development paradigms such as the deregulation of labour markets in tandem with the informalisation have weakened the power of trade unions as well as that of the state in all countries, irrespective of their unique circumstances. One area most affected by this reduced union and state power is the inspection and enforcement of labour standards, especially along value chains and among informal economy operators. A space has therefore been created for an emergence and a proliferation of new forms of labour standards governance, monitoring and regulation. These are made up of firm's self-regulation of labour standards and non-governmental systems. The viability of these options for labour standards governance remains a subject that requires interrogation for the purposes of analysis and policy. This paper is an attempt to fill this need by presenting a review of the existing paradigms. Regardless of the endemism of non-governmental regulation, this paper is grounded on the premise that non-governmental regulation mechanisms do constitute a viable alternative to state regulation. A combination of voluntary initiatives by firms, as well as monitoring and enforcement by the state is thus proposed.
\end{abstract}

KEYWORDS: Ghana, Labour, Regulation, Standards, Unions

\section{Introduction}

It has long been recognised that maintaining labour standards is a means of achieving social development alongside economic growth (Miles, 2015; Hoang \& Jones, 2012; Budd, 2004; ILO, 2004; Sengenberger, 2002). Traditionally, labour standards monitoring and enforcement has been the responsibility of national states and trade unions. However, the policy space available for developing 
countries has shrunk so much so that their ability to ensure high labour standards is being threatened. Recent global economic developments have weakened the power of trade unions as well as that of the state in all countries, regardless of their unique circumstances (Miles, 2015; Hoang \& Jones 2012; Jessop, 2011). The effectiveness of state regulation has therefore been questioned and even criticised. For instance, it has been reported that the traditional state regulation is costly, inefficient and has limited coverage. The essence of this criticism is now widely accepted, and has resulted in the emergence of, and interest in socially responsible initiatives (Jessop, 2011; Michelson, Jamieson \& Burgess, 2008; O’Rourke, 2005; O’Rourke, 2003; Sinclair, 1997).

The growing inadequacy and/or ineffectiveness of the traditional institutional system in enforcing and maintaining high labour standards have, therefore, created both the space and the need for alternatives. These are made up of firm's self-regulation as well as non-governmental systems which are venturing into activities that are traditionally the sole purview of the state, and other labour market institutions such as trade unions (O'Rourke, 2005; O'Rourke, 2003).The proliferation of alternative forms of labour standards governance is a growing trend that brings to the fore, the importance of firms being socially responsible to the point of initiating monitoring along their global chains and ensuring voluntary compliance.

Value chain analysis provides insights into why labour regulation has become so complex and therefore more difficult for state institutional systems to monitor and enforce. For instance, O'Rourke (2005: 11) reported that 'the complexities of supply chains have aided firms to hide behind multiple layers of ownership, making inspection difficult'. As a reaction to this, and in the quest for solutions, it has been proposed that powerful firms in a value chain may impress upon their suppliers and buyers to maintain higher standards as a condition for a continuous business contract. The existing scholarship on the subject has often focused on how socially responsible businesses are, or should be, in ensuring higher labour standards voluntarily as a matter of discretion (Christoperson \& Lillie, 2005; Frenkel \& Scott, 2002; Locke, Kochan, Romis \& Qin, 2007). By this, non-governmental regulation is claimed to be flexible and responsive to the complexities generated by value chains. Thus, while value chains have been blamed as a source of labour standards monitoring problems, they are more and more being acclaimed as a means to solving labour standards monitoring problems. Neglected however, is an interrogation of their viability in general as well as their potential to constitute a form of leverage for worker protection in developing countries like Ghana. This paper seeks to make a contribution in filling this gap. 
The paper is organised into four sections. It begins with a brief presentation of some theoretical perspectives relating to labour standards, then a review of literature on the new forms of labour standards regulation or non-governmental labour standards regulation and a discussion of a potential policy option for labour standards regulation.

\section{Theoretical Perspectives}

Theoretical positions on labour standards are polarised and may be grouped into two main categories: the market and non-market theories. The market-oriented neo-classical theory is currently the most influential. Such theorists, notably, Adam Smith, Marshall, Mill and Rostow, opine that, state intervention in any market including the labour market creates distortions. They advocate the retreat of the State, or at best a laissez-faire state in national economy. The general aim of the neo-classical approach to development is to recommend policies that will facilitate the development of the market system. According to them, economic underdevelopment is the result of distorted functioning of markets due to interferences by governments (and in the case of the labour market, trade unions and other institutions). Neo-classical economists argue that many labour markets are distorted by labour regulations and welfare nets, such as food subsidies, family and village support structures which prevent the real wage from falling to market clearing levels and misguided education policies leading to skill mismatches (Nicholas, 1998).

The neo-classical economic theory, from the ongoing, constitutes a major contribution to the trivialising of labour standards in employment relations. The thrust of neo-classical arguments in rejecting the strict enforcement of labour standards is that such standards could raise the cost of labour and create distortions in the labour market thereby preventing the free functioning of the labour market. This, in their view, can lead to slow growth or complete stagnation of the economy and hence hinder economic development (Hunt, 1989).Regarding the practicality of this model, Dawyne (1998) admits that the extent to which it is sufficiently adaptable remains an open and intriguing question. For reasons that are beyond the scope of this study, the neo-classical economic theory constitutes the backbone of the current wave of global capitalism albeit obvious indications that such theory is unworkable in many countries. Standing (1997) has mentioned de-unionisation, flexibility and its associated in security as some of the consequences of the neo-classical model, while Akorsu highlights informality and the operations of multinational corporations (2013; 2011). 
Discourses of political economy present one of the alternative views to neo-classical theory. Political economic theory is essentially about the way the understanding of economics informs political-decision making or policy formulation on the one hand and on the other hand, the manner in which political positions determine economic development or better put, socio-economic development. Political economic theory addresses concerns about equity and well-being of humans and that is what labour standards exist to achieve. Thus, by discussing political economic theory, an additional theoretical basis is being provided for ensuring rights at work. Earlier political economic approaches include utilitarianism and Rawl's theory of justice. To Sen, however, both utilitarianism and Rawl's theory of justice have serious defects that cannot be relied on as guide. He argues that both theories suffer from instrumentalism. They both focus on the means, rather than the ends of development. Measuring the values such as happiness is impossible without making inferences about something which is difficult to observe. Though attempts have been made to measure utility, for instance with GDP per capita, Sen considers this as flawed in the sense that it ignores inequalities. Also, the Rawlsian emphasis on the most disadvantaged eliminates those who are neither well off nor among the most disadvantaged and the question of how the disadvantaged in society are identified is left unanswered. Thus, in response to the difficulties with these approaches, Sen develops his perspective on capabilities and functioning. The functioning is the constitutive elements of welfare - being nourished, being educated, being free to pursue one's own ends, etc. - and the capability is the ability to achieve the functioning. Thus, Sen (1999) argues that, in dealing with extreme poverty in developing countries, substantial progress can be made only when centrally important functioning and their associated basic capabilities are satisfied. The importance of Sen's contribution is in his emphasis on improvements in the quality of lives of people through freedom as constituting of ability and access to good health, nourishing food, education, and participation in decision making.

The human development concerns outlined in UNDP (2000) are a reflection of Amartya Sen's classic view of development as freedom. The work of Sen has thus been influential in shaping a new thinking about development - the way societies are managed both politically and economically. In the attempts to improve the quality of lives, it has been realised that improving the quality of employment is crucial. After all, labour is the only asset for the poor (Budd, 2004). It has therefore been widely acknowledged that until labour is adequately protected and rewarded in a way that emphasise rights to decent employment and incomes in line with the ILO Decent Work framework, issues of equity will continue to be a worldwide canker (Budd, 2004). The need to ensure that work conditions are protected has 
become even more crucial in this era of global capitalism, with its associated informality. This is especially so because market capitalism tends to generate economic inequalities that undermine political equality and thus democracy (Swanson, 2007). Thus, Dahl (1985) argues that the internal control and leadership of business enterprises should be seen as a type of government and therefore susceptible to the same arguments made for democratising the governments of states. While this seems overly ambitious politico economic rhetoric, he argues that it can be resourcefully used to understand the specific consequences of diverse market institutions and how they might be altered to more effectively meet various democratically negotiated social goals (Dahl, 1989). To this end, governments, as well as trade unions have important roles to play. According to Swanson (2007), government processes will then determine whether particular markets are organised and operate in a manner that is socially beneficial and supportive of democracy. This is where the state and other institutional instruments come into the discourse as important regulatory frameworks for harnessing the economy or, if you like, enhancing efficiency (rationality) and equality (social distributive justice).

The institutional theory, also non-market, upholds the main actors in the labour market: trade unions, employers and the government, with their associated bargaining processes, which produce outcomes like the details of payment conditions and the legalities of work contract (Bennett and Kaufman, 2007). This school acknowledges a vital role that the government plays as a mediator in conflicts (Müller-Jentsch, 2008). Thus, governments, through intervening in education, manpower and social policies, create an environment for industrial democracy, which is fundamental to human dignity (Harrison and Freeman, 2004; Kaufman, 2004; Budd, 2004). These interventions serve the good purpose of protecting the weak, unprotected, unorganised and low skilled workers in the markets. The dominant view people have of institutions is that they are a set of habits, attitudes, conventions, rules, values and norms that regulate social interactions. For instance, North (1990: 3) defines institutions as "the rules of the game in society ... the humanly devised constraints that shape interactions". Parsons (1990) also suggests that institutions are sets of norms that regulate the relations of individuals to each other thereby determining what such interactions ought to be.

The implication of this understanding is that labour standards are in fact, institutions in themselves since labour standards are the norms or rules that regulate or govern working conditions and labour relations. Elster (1989) also states that, what makes an institution is not the rules or conventions per se but 
those instruments and mechanisms that ensure that a particular set of rules are applied. This emphasis on enforcement is also highlighted by North (1986) when he suggests that institutions entail enforcement either of the self-enforcement variety through codes of human behaviour, or by third-party policing and monitoring. It is worthy of note, however, that labour standards are not among the self-enforcing type of institutions. By their very nature, labour standards invoke defiance since such defiance may be considered economically rational. It is within this view of institution that the discourse of labour standard regulation and monitoring can be positioned and understood. Unlike some forms of institutions, labour standards are not among the self-enforcing type of institution. Another important view of institution has been the inclusion of organisational structures.

Clearly, the literature has therefore been fraught with what can be described as ideological battles rather than focussing on the development of an integrated theory for labour market analysis and for an effective labour standards application at this crucial time of economic globalisation.

\section{Labour Standards Regulatory Forms}

There has been an emergence and a proliferation of new forms of labour standards governance, monitoring and regulation. These are made up of firms' self-regulation as well as non-governmental systems which are venturing into labour standard monitoring and regulation, activities that are traditionally the sole purview of the state, and other labour market institutions such as trade unions. Regarding what constitutes non-governmental labour governance and regulation, O'Rourke (2005: 2) states that they involve multiple actors with new roles and relationships, experiencing new processes of standard setting, monitoring, benchmarking and enforcement. Martínez Lucio and Mackenzie (2004: 80) confirm that it is a multi-stakeholder system that involves different actors. Thus, while traditional regulation has been located within three main sites with distinct activities, regulation in its current form entails more sites and even more activities as depicted in Figure 1. No wonder it is described as "more diverse and messier" than the traditional command and control system (O’Rourke, 2003:5). 


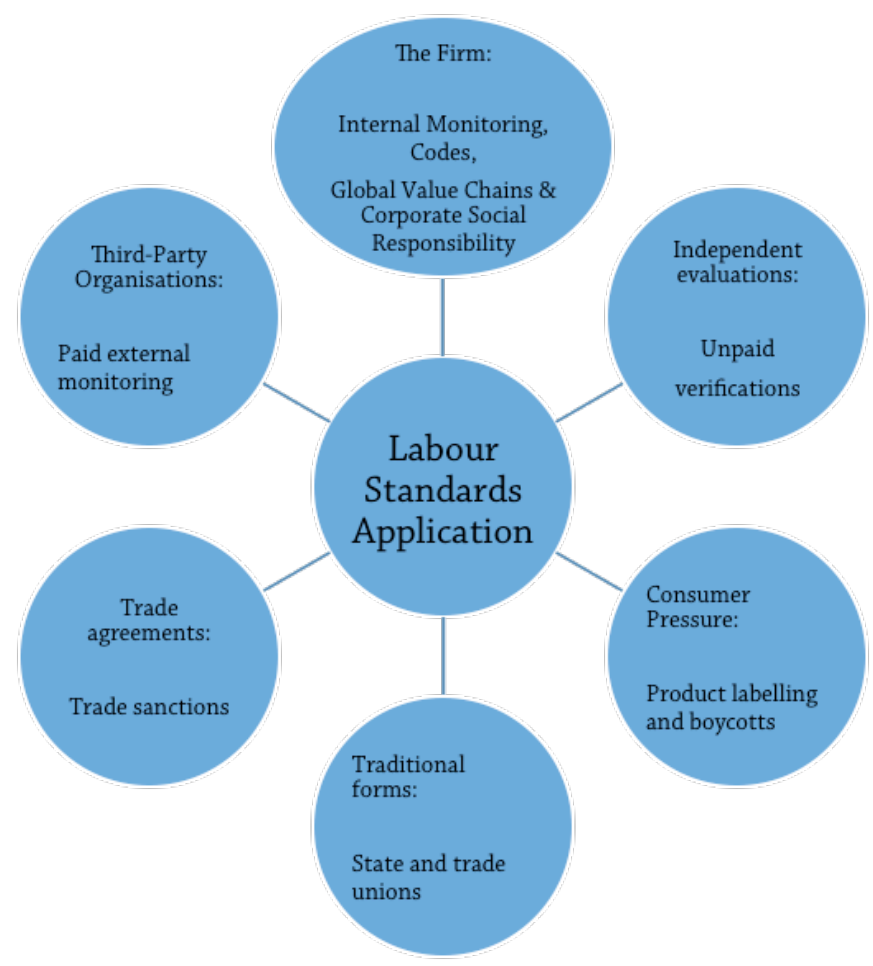

\section{Figure 1: Current forms of market driven regulation systems}

Source: Akorsu (2010)

The sites for the new forms of regulation reside in the firm itself and its supply chains, non-governmental/non-profit making organisations, trade union organisations, profit-making monitoring organisations, civil society pressure groups and, even in some cases, industry associations. Firms are moving away from simply complying with labour standards out of fear of prosecution and are moving towards taking initiatives voluntarily. These initiatives often start with the enacting of company specific codes of conduct that guide the firms' operations and often extend to monitoring the firms in the supply chain. The firm-specific codes are based on the principle of corporate social responsibility and they emphasise labour standard issues. With regard to initiatives from the firm, these are based on the principle of voluntarism, but voluntarism that is motivated by pressure from labour and human rights groups. Characteristically, such initiating firms are branded firms (Miles, 2015; Hoang \& Jones 2012; O’Rourke, 2005; 2003). These firms are said to ensure compliance along their supply chain by regularly monitoring the firms in the supply chain and in cases of violation, abrogating contracts with such firms. Thus, the rules of the game are set by the firm just a sits enforcement 
and issuing of sanctions are all done by the firm - Internal or firm-specific selfregulation.

Another site for the current non-state regulation is located with external monitoring organisations. This is where firms submit to the monitoring by external bodies. This monitoring may either be based on the firms' codes of conduct or the standards developed by the external body and even guidelines developed by multi stakeholder organisations. The monitoring organisations, according to O'Rourke (2003), are paid salaries by the firm being monitored and may provide certification and these certificates they issue are increasingly being used as a trade licence. A third site of the new regulation is by means of international labour unions or independent bodies that respond to the needs of employees. Often, these responses are based on complaints from unions or groups like Workers Rights Consortium (WRC) who initiate campaigns to raise public awareness and to pressure brands and/or retailers to change conditions. Sometimes, these campaigns take the form of negotiations (Weil \& Mallo, 2007). As has been indicated by O'Rourke (2003), monitoring organisations in this category are not paid salaries by the firm and categorises their kind of monitoring as verification.

The above broad descriptions of the new forms of regulation are not exhaustive but clearly demonstrate that indeed, they are diverse and messy in their conceptualisations. It is difficult to concisely and accurately categorise the various forms since there are all kinds of overlaps. This new surge has not occurred in a vacuum, but has been attributed to the absence of, or weak national and international regulations of labour standards. According to Sinclair (1997: 530):

Command and Control regulation is accused of being costly and inefficient, of stifling innovation, inviting enforcement difficulties and focussing on end-of-pipe solutions. This critique, the essence of which is now widely accepted, has sparked considerable interest in various types of regulatory alternatives.

Even though, there are weaknesses in traditional regulatory systems or command and control systems, to conclude that it is the root cause of the proliferation of nongovernmental systems is misleading. There may be other and even more powerful pointers. For instance, O'Rourke (2005: 1) states that these new forms of regulation have been necessitated by trends in the weakening of national regulatory systems, the strengthening of multi-national corporations and the growing demands from civil society for a more effective corporate accountability which are also the result of recent accounts of increasing sweetshops and deplorable working conditions of work. This appears to be a more balanced explanation: while admitting the 
weaknesses in national regulation as the failure of state bureaucracies, O'Rourke (2003: 4) does not gloss over such weaknesses but establish that it is 'due to globalisation and neo-liberal movements to shrink the state'. Also, Martínez Lucio and Mackenzie (2004: 8) observe that 'the new form of regulation is becoming much more complex and subsequently more politicised than may be expected'. The strong presence of neo-classical ideology cannot be overlooked in the analysis of the trend that is gaining so much momentum.

The non-governmental regulation has been called a complementary regulation mechanism of the ineffective and inadequate command and control regulation. It has also been viewed by some as innovative and flexible in dealing with the inherent complexities involved in regulating international supply chains, and also as responsive to the changing trends in work organisations (Weil \& Mallo, 2007; Cashore, 2002; Nadvi \& Wältring, 2001). Though the new regulation is still an emerging development which is yet to be critically assessed, Esbenshade (2001: 5) reports that:

They have significantly raised the rate of compliance in industry ... by 20\% between 1994 and 1996... However, the data also demonstrate that while monitoring helps, it has far from solved industry's problems. Fifty six percent of monitored shops are still violating labour laws.

Indeed, the new forms of regulation are an intriguing development. In the main, the strongest ideological underpinning of these new regulation systems is that they are market-based and therefore oppose the traditional state regulation. However, Chang (1996: 132) opines that, the efficient operation of the market depends on many institutional arrangements and that the seemingly 'institution free' market mechanisms are sustainable only as a part of the intricate fabric of various institutions. What this means, therefore, is that neither the market nor the state nor any other institution can perfectly manage or regulate labour market operations. According to Chang, each has its strengths and weaknesses and therefore may work better under certain conditions and worse, depending on the conditions (Chang, 1996: 135). Thus said, it is important for each country, especially developing countries like Ghana, to determine the level of coordination between the state, the market, and other institutions based on local conditions that are unique.

Another argument against the regulation by the state has been the cost involved. 'Command and control regulation is accused of being costly and inefficient. This critique, the essence of which is now widely accepted, has sparked considerable interest in various types of regulatory alternatives' (Sinclair, 1997: 530). In this 
regard, one wonders if the new regulation is the best solution to the problem of cost. This is because, the issue of cost has been, and will always be of even more importance to firms as profit maximising entities. It thus appears, however, that firms are no longer concerned about the cost of applying labour standards, since many firms are now willing and able to voluntarily implement labour standards and are even paying for third-party monitoring services. Without a doubt, all these efforts are commendable and definitely steps in the right direction but if firms are able and willing to bear the cost of labour standard monitoring out of genuine concern to uphold higher standards, it behoves them then to rather support the state financially in the discharge of their traditional role of monitoring labour standards. After all, the states already have the supporting institutional arrangements as well as the experience to handle the daunting task of monitoring labour standards application within firms.

The possibility for firms to financially support the state is important given the fact that firms, like the state, are also under pressure. They themselves are facing serious challenges in the face of increased global competition. After all, the whole idea of sub-contracting and value chains came into being because firms sought ways to ease themselves of some of the burdens of production and to focus on their core competencies. This is why taking up the rather heavier load of regulating the market is puzzling. It is, therefore, no wonder that the new regulation has been said to face 'many of the same mundane challenges as traditional government monitoring and enforcement - coverage, training, and capacity of inspectors, incentives for monitors, corruption and so forth' (O'Rourke, 2005: 11). Some authors have pointed out that the assumption that the transfer of regulation will be met with willing, able and adequately resourced economic organisations is questionable (Miles, 2015; Hoang \& Jones 2012; Ruwanpura, 2011, Thomas, 2011, William, Heery and Abbott, 2011). Martínez Lucio and Mackenzie (2004) argue that labour market regulation as it is known now requires a significant set of organisational strategies as well as coherent political strategies. These strategies are the historical legacies and contours of social and political organisations that shaped the effectiveness or otherwise of traditional regulation, with trade unions as important forces (Martínez Lucio and Mackenzie, 2004: 89).

Thus, the interest in self-regulation as an alternative from industry's perspectives is the emphasis on voluntarism and the absence of compulsion (OECD, 1994). In fact, Sinclair (1997) reports that industry's natural aversion to government intervention is enough to overcome any reservations about assuming costs associated with self-regulation. The new regulation, however, cannot be described as the best alternative to the traditional state regulation. Sinclair also opines that 
'the ideal of an essentially cooperative and voluntary approach is also extremely difficult to attain and a complete absence of compulsion is, in fact, rare, even for ostensibly pure self-regulatory initiatives' (Sinclair, 1997, p. 535). Additionally, Martínez Lucio and Mackenzie (2004: 89) indicate that:

the reality is that the state still takes up a sizable share of the economic sphere of most countries... the role of the state in terms of the welfare function has not diminished regardless of the adoption of 'market/ private-sector' techniques.

These are indications that on the one hand, firms have used self-regulation to delay impending state regulation and on the other hand, states have relied on selfregulation to achieve compliance.

The capitalist dynamics of the new regulation is also worth mentioning. According to O'Rourke (2005: 11), the complexities of supply chains have aided firms to hide behind multiple layers of ownership and have made inspections difficult. Firms are controlling the regulatory processes in unimaginable ways - ways that have been described by Justice (2001), as co-opting the non-governmental organisations from monitors to partners and undermining regulatory laws and unionisation. The fact that some of the NGOs are paid by the monitored firm also is suggestive of the tendency to breed corruption. It is not surprising, therefore, that most NGOs provide ineffective monitoring. For instance, they ridiculously give prior notice to firms before inspections, depend largely on data from management, hold interviews with workers within the factory when factory managers know who is being interviewed, on what issues and for how long (O'Rourke, 2002). Certainly, this kind of monitoring is only a capitalist tactic or a decoy, which diverts attention from the actual objective of ensuring higher labour standards to issues of public relations.

Even in the few cases where monitoring appears effective, the potential to subcontract the more hazardous jobs to smaller and micro enterprises within the informal economy renders such issues elusive. There is also the tactic of deliberate contradictions. As Christopherson and Lillie (2005: 1933) put it:

the contradiction between the IKEA low-cost competitive strategy ... and the desire to maintain the image of standards and in the case of WalMart, the pressure to continue to produce high returns for shareholders every quarter fosters the most rapacious and extreme forms of supplier squeezing [with the] inevitable consequences. 
Thus, while a firm may be impressing upon its suppliers to maintain higher standards, the pressure on the suppliers to cut down cost makes upholding higher standards impossible. This makes it extremely difficult to identify where the commitment of businesses actually is. There is obviously a strong presence of the conflict of interest in self-regulation, which cannot be taken for granted.

On the issue of firm-specific codes of conduct, though they have been described as originally diverse, O'Rourke (2003: 7) asserts that 'they now appear to be converging around the ILO core standards' as well as some of its non-core standards. It should be noted, however, that such convergence claimed by O'Rourke here is no guarantee of credibility of such codes for albeit touching broadly on the core principles of the ILO, the very details of such firm-specific codes are remarkably still very diverse (van Tulder, 2001). Thus, to simply assume that firm-specific codes of conduct are addressing all the salient principles of the ILO that have been internationally agreed upon and adopted as universally binding is to minimise the importance of the international standards. The tendency is to eventually miss the original objective of these standards. More importantly, firm-specific codes of conduct are not laws. This means they can be violated with impunity. For instance, Arthurs (2001: 480) writes regarding codes that:

The language of codes is vague, hortatory and not well suited to compelling compliance in circumstances which are unclear or controversial... no coercive power is available to enforce voluntary codes...code, then, are, at best only a rough approximation of liberal legality, not a strict replication of it.

When it comes to labour standards application, overly focussing on firm-specific codes of conduct will mean eliminating most firms. The reality is that codes are not universal; they are developed and adopted by only some firms - often branded and powerful multinational corporations that are sensitive to public relations. Many, if not all, local firms in developing countries can be described as small and micro enterprises who cannot afford and sustain self-regulation. Thus, if the certification from these third-party monitoring bodies becomes a trade licence, many of these small firms will eventually cease to exist, which in turn has several implications. For such firms, addressing the real problems of the traditional state regulation is crucial since the new regulation cannot be a viable solution to the so-called problems with state regulation. It has therefore been conceded that:

within a situation of reduced union power, continuing antagonistic capital-labour relations and the growing irrelevance (or reduced role) of national labour regulations, the promotion of "decentness" and "good" 
governance of labour rights and conditions may not find an adequate substitute in new forms of international standards and regulations (Knorringa \& Peglar, 2004: 7).

Thus, besides the issues of legitimacy, accountability, rigour, enforcement and transparency, one important gap that the new regulatory systems are unable to fill is the issue of coverage. The general lack of capacity among the numerous small and micro enterprises in developing African countries renders selfregulation improbable. In this regard, this review is important since it resonates the peculiarities of Ghana as a typical African state with enterprises, which have been neglected in the current scholarship on labour standards regulation. Elster (1989) is therefore right in opining that, what constitute an institution are not the rules or conventions per se, but those instruments and mechanisms, which ensure that a particular set of rules are applied. This emphasis on enforcement was also highlighted by North (1986) when he suggested that, while some institutions may be self-enforcing, others need third-party policing and monitoring. Indications are that labour standards are definitely not among the self-enforcing type of institutions. By their very nature, labour standards invoke defiance since such defiance makes economic sense. Since labour standards are not self-enforcing, the role and importance of external bodies or institutions in promoting the application of such standards cannot also be overlooked despite their own internal difficulties.

\section{Towards an Integrated Framework for Labour Standards Application}

Ultimately, the discussions in the paper have demonstrated that while concepts such as decent work and consumer pressure are motivated by social justice goals, and are initiated outside the business organisation, others such as trade agreements and CSR are motivated by market efficiency goals. These debates present insights into the global institutional context, within which labour standard issues can be appreciated. The fact that the outcomes from each paradigm and its associated mechanisms alone have not necessarily led to labour standards application has also been highlighted, hence, providing an additional reason for an integrated approach. Having set the theoretical and conceptual stage, an integrated framework which can aid future theorisation on labour standards is developed in this section. The section examines how the conflicting objectives of the various existing paradigms can be brought together for the analysis of labour standards application. The main gap identified in existing literature is that theoretical perspectives relating to labour standards are polarised into two main categories, namely, the market and non-market theories, and are fraught with 
confrontations between efficiency goals and social goals to the extent that they have become ideologically loaded and non - applicable in many circumstances. The neo-classical theory constitutes the market theory while theoretical perspectives such as the institutional economic theory and the political economy theory constitute the non-market theories. What this means is that there are two broad and competing objectives in the labour market. Each of these has given rise to a number of institutions and institutional arrangements which ultimately have implications for labour standards application. These conflicting ideologies have degenerated into what can be described as ideological battles rather than focusing on the development of an integrated theory for labour market analysis. This is where the major gap in the literature lies and therefore, this is where one of the major contributions made by this study also lies. A new way of theorising and conceptualising labour standards application was therefore found to be highly needed.

The importance of developing an integrated theory for the labour standards analysis also derives from the fact that on their own, none of the conflicting theoretical dispensations can effectively explain the multifaceted nature of labour standards. Also, the particular contexts within which labour standards are applied in developing countries like Ghana call for a targeted effort towards theorisation. Here, a summary of what could be considered the most demanding and challenging theoretical and analytical task is presented. First, labour standards represent social interests, and a strong social structure remains a necessary condition for the operation of markets, suggesting that social interests are an integral part of economic interest or at least should be a part. At the same time, promoting efficiency leads to growth, which results in the creation of sustainable businesses and employment. There cannot be employees if there are no businesses to employ people. Coming as a tandem to growth then, labour standards could easily be adopted and applied., That said, raising the extremely important labour standards - not keeping them low or ignoring them - should be embraced as a reliable source of competitiveness, since it improves the quality and productivity of labour among other things. In fact, there is no justification for trade-offs. In fact, market efficiency and labour standards are not mutually exclusive.

Thus, sacrificing social or labour standards for efficiency gains may just be an appealing short-term strategy with definite and substantial long-term costs. In view of this, overly emphasising the market-oriented neo-classical economic theory at the expense of the social tenets espoused by other non-market theories like the institutional economic theory and political-economy theory technically implies working against efficiency. The institutional school upholds the main 
actors in the labour market: trade unions, employers and the government, with their associated bargaining processes, which produce outcomes that protect the relatively weak workers from capitalist exploitations in the labour markets. The political economic theory also addresses concerns about equity and well-being of humans and these are what labour standards exist to achieve.

It is therefore recommended that the overly dominant and intimidating role of the neo-classical economic theory be minimised, since such "ideological hegemony" (as Stiglitz, 2002 calls it) is destructive. While this is not to suggest that efficiency goals should be eliminated completely, the suggestion is to place equal, if not more emphasis, on the existing non-market or socially oriented theories such as the Institutional Economic Theory and the Political Economic Theory. In that case, both efficiency and social protection goals will be projected. This will lead to the creation of viable and sustainable businesses as well as the creation of strong trade unions and civil societies respectively. The main proposal here is a move away from antagonistic tendencies and to aim at balancing the efficiency and social protection interests through consultations and dialoguing at both the international and national levels.

What makes dialoguing appealing is the whole process of negotiating proposals and conditions which would have been imposed. In general, dialoguing is an acknowledgement of the crucial role of cooperation, in dealing with various issues such as unemployment, inflation and productivity as well as the more traditional issues of wages and conditions of work. As a result of dialoguing, voluntary compliance as currently projected by the non-governmental regulation can be strengthened and complemented with the traditional monitoring and enforcement. The proposed cooperation also means that firms will tend to aid the state's access to their complex value chains for effective monitoring rather than hiding behind complex chains to lower standards.

\section{Conclusion}

The paper has highlighted the weaknesses in new regulatory mechanisms which have been suggested as alternatives to the traditional state regulation. Left to the discretion of companies, labour standards application is unlikely to be taken seriously and if taken seriously, it would be limited to few large and powerful multinationals that can afford it and that have an image to preserve. Over-reliance on such mechanisms, therefore, can only continue to be an ideal rather than a reality. Thus, a viable option for labour standards monitoring, enforcement and governance appears to be a combination of voluntary initiatives by firms and 
enforcement by the state. By this, the strengths in both regimes will be harnessed as leverage for the protection of vulnerable workers in Ghana and other developing African countries. In practical terms, socially responsible firms can then support the efficient operation of the traditional system by contributing to a common fund to aid labour inspection, rather than by paying for independent monitoring.

\section{References}

Akorsu, A.D. (2013). Labour management practices in the informal economy of Ghana: The patterns and pressures. Economic Annals, LVIII (196), pp.157-176.

Akorsu, A.D. (2011). Labour standards application among multinational and domestic firms in Ghana's manufacturing sector, Economic Annals, LVI (189), pp. 51-68.

Akorsu, A.D. (2010). Labour standards application in Ghana: Influences, patterns and solutions. (Unpublished PhD Thesis): University of Manchester, Manchester.

Arthurs, H.W. (2001). Private ordering and workers right in the global economy: Corporate Ccodes of conduct as a regime of labour market regulation. In $\mathrm{J}$. Conaghan, K. Klare \& M. Fischl, (Eds.). Transformative Labour Law in an Era of Globalisation. Oxford: Oxford University Press.

Bennet, J.T. \& Kaufman, B.E. (eds.) (2007). What do unions do? A twenty-year perspective, New Brunswick, NJ: Transaction Publishers.

Budd, J.W. (2004). Employment with a human face: Balancing efficiency, equity and voice. Ithaca, NY: Cornell University Press.

Cashore, B. (2002). Legitimacy and the privatisation of environmental governance: How non-state Market Driven (NSMD) Governance Systems Gain Rule Making Authority. Governance,15, pp. 503-529.

Chang, H.J. (1996). The political economy of industrial policy. London: Macmillan Press Limited.

Christopherson, S. and Lillie, N. (2005). Neither global nor standard: Corporate strategies in the new era of labour standards. Environment and Planning, 37, pp. 1919-1938.

Dahl, R. A. (1985). A preface to economic democracy, Berkeley, University of California Press.

Dahl, R.A. (1989). Democracy and its critics, New Haven, Yale University Press.

Dawyne, B. E. A. (1998). Labour market economics - Theory, evidence and policy in Canada, Toronto, McGraw-Hill. 
Elster, J. (1989). Nuts and bolts for the social sciences. Cambridge: Cambridge University Press.

Esbenshade, J. (2001). The social accountability contract: Private monitoring from Los Angeles to the global apparel industry. Labour Studies Journal, 26, pp. 98120.

Frenkel, S. \& Scott, D. (2002). Compliance, collaboration and codes of labour practice: The Adidas Connection. California Management Review, 45, pp. 29-48.

Harrison, J.S. and Freeman, R.B. (2004). Democracy in and around organisations: Is organisational democracy worth the effort? Academy of Management Executive, 18, 49-53.

Hoang, D. and Jones, B. (2012). Why do corporate codes of conduct fail? Women workers and clothing supply chains in Vietnam. Global Social Policy. 12(1) pp. $67-85$.

Hunt, D. (1989). Economic Theories: Analysis of competing paradigms, Wheatseaf, Harvester.

ILO. (2004). International abour standards. Geneva: International Labour Organisation publication.

Jessop, B. (2011). Rethinking the diversity and variability of capitalism: on variegated capitalism in the world market. In C. Lane \& G. Wood (eds.). Institutions, Internal Diversity and Change. London: Routledge.

Kaufman, B.E. (2004). The global evolution of industrial relations: Events, ideas IIRA, Geneva, International Labour Organisation.

Knorringa, P. and Peglar, L. (2004). Perceptions of labour rights and conditions: SME and global value chains. EADI Workshop. Amsterdam.

Locke, R., Kochan, T., Romis, M. \& Qin, F. (2007). Beyond corporate codes of conduct: Work organisation and labour Standards at Nike's Suppliers. International Labur Review, 146, pp. 21-40.

Martinez Lucio, M. and Mackenzie, R. (2004). 'Unstable boundaries?' Evaluating the 'new regulation within employment relations. Economy and Society, 33, pp. 7797.

Michelson, G., Jamieson, S. and Burgess, J. (eds.). (2008). New employment actors: Developments from Australia. Bern: Peter Lang.

Miles, L. (2015). The 'integrative approach' and labour regulation and Indonesia: Prospects and challenges. Economic and Industrial Democracy. Vol. 36(1) pp.522. 
Müller-jentsch, W. (2008). Industrial democracy: Historical development and current challenges. Management Review, 19, 260-73.

Nadvi, K. \&Waltring, F. (2001). Making sense of global standards. Draft IDS-INEP Working Papers, Institute of Development Studies. Sussex.

Nicholas, H. (1998) Theories of economic development. Unpublished Lecture Notes, Institute of Social Studies, The Hague.

North, D.C. (1990) Institutions, institutional change, and economic performance, Cambridge, Cambridge University Press.

North, D.C. (1986). The new institutional economics. Journal of Institutional and Theoretical Economics,142, pp. 238-245.

O'Rourke, D. (2003). Outsourcing regulation: Non-governmental systems of labour standards and monitoring. Policy Studies Journal,31, pp.1-29.

O’Rourke, D. (2005). Multi-stakeholder regulation: Privatizing or socialising global labour standards? Berkeley: University of California.

Parsons, T. (1990). Prolegomena to a theory of social institutions. American Sociological Review, 55, 319-339.

Ruwanpura, K.N. (2011). Women workers in the apparel sector: a three decade (r)evolution of feminist contributions? Progress in Development Studies. 11(3), pp. 197-209.

Sen, A. (1999). Development as freedom, Oxford: Oxford University Press.

Sengenberger, W. (2002). Globalisation and social process: The role and impact of international labour standards. Bonn: Friedrich-Ebert-Stiftung.

Sinclair, D. (1997). Self-regulation versus command and control? Beyond false dichotomies. Law and Policy, 19, pp. 529-559.

Standing, G. (1997) Globalisation, labour flexibility and insecurity: The era of market regulation. European Journal of Industrial Relations, 3, pp. 7-37.

Swanson, J. (2007). The economy and its relation to politics: Neoclassical Economics and Democracy. Polity, 39, pp. 208-233.

Thomas, M.P. (2011). Global industrial relations? Framework agreements and the regulation of international labor standards. Labor Studies Journal, 36(2) pp. 269-287.

UNDP (2000). The human development report 2000, New York: Oxford University Press. 
Van Tulder, R. \& Kolk, A. (2001). Multinationality and corporate ethics: Codes of conduct in sporting goods industry. Journal of International Business Studies, 32, pp. $267-283$.

Weil, D. \& Mallo, C. (2007). Regulating labour standards via supply chains: Combining public/private interventions to improve workplace compliance. British Journal of Industrial Relations, 45, pp. 791-814.

Williams, S., Heery, E. \& Abbot, B. (2011). The emerging regime of civil regulation in work and employment relations. Human relations. 64(7) pp. 951-970. 